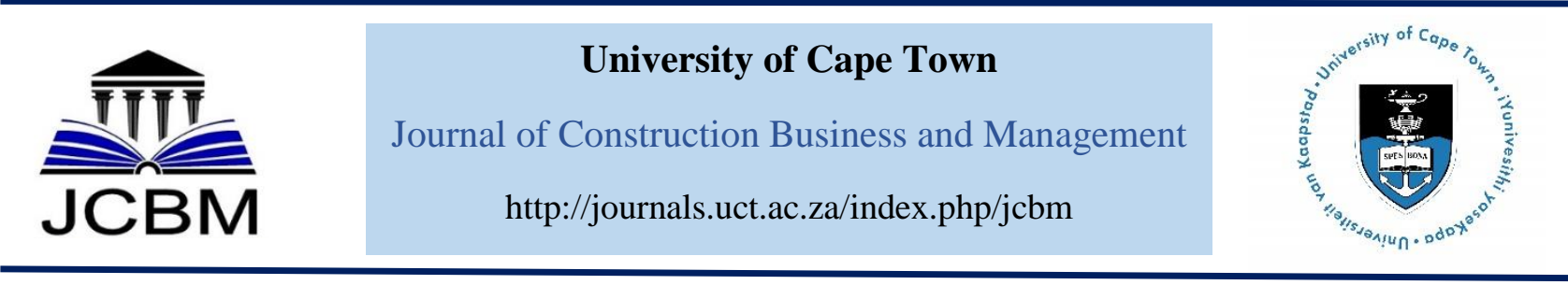

\title{
A Career Path Framework for Quantity Surveyors in Nigeria Private Practice
}

\author{
J. O. Dada ${ }^{1}$ \\ ${ }^{1}$.Department of Quantity Surveying, Obafemi Awolowo University, Ile-Ife, Nigeria
}

Received 1 June 2017; received in revised form 16 August 2017, 21 June 2018; accepted 27 June 2018 $\underline{\text { https://doi.org/10.15641/jcbm.2.2.2018.94 }}$

\begin{abstract}
In a typical organization, career path helps employees to understand what is expected of them based on the positions they occupied. This also allows them to participate in managing their career progress. Many quantity surveying firms do not have career development path for their quantity surveyor (QS) employees and this has limited their performance at work. This paper, therefore, develops a career path framework for quantity surveyors in private practice in Nigeria. A combination of survey and interviews were employed to elicit the required data. The study population are in two categories. Firstly, the quantity surveying firms, while the respondents in the firms are the principal partners and their employees. The second category is the chairmen of the state chapters of the Nigerian Institute of Quantity Surveyors. The findings of the study establish the career path progression for a quantity surveyor in private practice which ranges from trainee quantity surveyor, assistant quantity surveyor, quantity surveyor, senior quantity surveyor, principal quantity surveyor, chief quantity surveyor, partner and principal partner/consultant in that order. The proposed conceptual framework signifies and demonstrates the necessary benchmark to resolving common problems about career progression and development among quantity surveyor in private practice. This is seen as having a positive effect on harmonious working relationship and quality service delivery. Keywords: Career development, Career path, Framework, Nigeria, Private Practice, Quantity Surveyors.
\end{abstract}

\section{Introduction}

The world has witnessed and still witnessing massive changes in technology, social, political and economic orders. Many of these changes appear as threats to the quantity surveying profession but only to the pessimist because more significant opportunities have been and are still being created (Ikedionwu, 2016). The Quantity surveyor plays a significant role in the management of construction projects by acquiring and deploying appropriate competencies (Nkado and Meyer, 2001). The exact nature of their role depends on who employs them. The professional quantity surveyor engaged by the client and the contractor's quantity surveyor have different roles to play in any construction project. The contractor's quantity surveyor role is far more than measurement and quantification but extends to administration and commercial management of construction contract (Towey, 2012). VFM Group (2008) summarized the principal role of a Chartered Quantity Surveyor in ensuring that the building client receives value for money.
Back in 1971 the Royal Institution of Chartered Surveyors (RICS) defined the traditional role and described the distinctive competence of the quantity surveyor as a skill in measurement and valuation in the field of construction in order that such work can be described, the cost and price forecasted, analysed, planned, controlled and accounted for. However, Phen and Ming (1997); RICS (1993); RICS (1998); BQSM (2004); Arifin and Torrance (2008); AIQS (2004); PAQS (2001) Githaiga (2004) and, Chiu and $\mathrm{Ng}$ (2015) explicitly highlighted the role of quantity surveyor in private practice. These include feasibility study, development appraisal, cost planning and control, contract documentation and administration, project management, procurement management, risk management, litigation, arbitration and dispute resolution, technical auditing and valuation for fire insurance.

Growth or progress, in any profession, is expected or made when one climbs from one level to higher one either by having more knowledge, acquiring more skills or having higher output. (Anunike, 2016). Grugulis (2003) opined that qualifications could help employers identify

\footnotetext{
${ }^{1}$ Corresponding Author. Tel: +234 8035729341

Email address: debbyjoe2002@yahoo.com
} 
suitable employees, provide individuals with portable credentials, and give occupational groups bargaining power. This notwithstanding, there is dichotomy in quantity surveyors' recruitment, placement and promotion in private practice when compared with those in public service in Nigeria. In public service, there exists a regulated scheme of service for all cadres of staff irrespective of their professional affiliation, but this is not the case in private practice primarily for quantity surveying. This makes it difficult for employees to put in their best in such an organization where there is no clear plan on how they will progress on their jobs over the years.

Thus, it is of considerable importance to have in place a formal career path system for quantity surveyor employees in private practice. This is seen to take account of and encourage the career management of prospective employee which is vital to high-quality service delivery. The purpose of this paper, therefore, is to provide a career path framework that could serve as a regulated scheme of service and career pathway metrics for quantity surveyors in private practice. In doing this, a literature review, to clarify the theory and key concepts that provided the background for the study, was first conducted. This is followed by the explanation of the research and analytical methods. The findings and results were thereafter presented and discussed.

\section{Literature Review}

\subsection{The Theoretical Concept}

Collins English Dictionary (2012) defined career as a person's course or progress through life. This definition relates career to a range of aspects of an individual's learning and work through life. According to Hrzone (2016), career paths are routes that individuals take from their first engagement into the job market through to their final position before retirement. This definition can be expanded to include even after retirement. National Career Pathways Network (2012) defined career pathway as a coherent, articulated sequence of rigorous academic and career or technical courses, commencing in the ninth grade and leading to an associate degree, baccalaureate degree and beyond, an industry-recognized certificate, and licensure. Simply put, career pathways are a method of developing and organizing curricula across different strands of careers. The teaching, counselling, and assessment that support career pathways are also designed to focus students toward career goals beyond graduation, the result being passports and a portfolio as evidence of work readiness. The objectives of career pathways are to help students or employees to understand and consider career options, discover workplaces and their relationship to curricula, make choices about future education and training, understand the expectations for achieving career goals, maintain portfolios of progress and achievement, and become flexible but focused employees.

Heathfield (2014) defined career pathing as the process used by an employee to chart a course within an organization for his or her career path and career development. It involves understanding what knowledge, skills, personal characteristics, and experience are required for an employee to progress in his or her career laterally or through access to promotion. Society for Human Resources Management (SHRM) (2015) viewed career development as the process by which individuals establish their current and future career objectives and assess their existing skill, knowledge or experience levels and implement an appropriate course of action to obtain their desired career objectives. A career development model facilitates this process by providing pre-defined career paths or ladders which SHRM defines as the "progression of jobs in an organization's specific occupational field ranked from the lowest to the highest hierarchy. Career management describes the active and purposeful management of a career by an individual. Ideas of what comprise "career management skills" are described by the Blueprint model/framework (in the United States, Canada, Australia, Scotland, and England (Hooley, et al (2013)) and the Seven C's of Digital Career Literacy (specifically relating to the Internet skills (Hooley, 2012).

\subsection{The significance of career path model or framework in an organisation}

Career path frameworks are often used to describe the progress path of an individual in an organization. Hollmann and Elliot, (2006) viewed this as a technical ladder. Once a model or platform is created, the organization has all the information needed to readily create job description and job postings as needed, with assurance that the job posting meets business requirements as well as specific job requirements. The career path approach, according to Centre for Postsecondary and Economic Success (2013), strengthens existing education and workforce services from a myriad of disconnected programmes to a structure that focuses on the individuals in need of education and training and their career paths. It provides clear transitions, strong supports, and other elements critical to the success of participants. Giamalvo (2016) presented a five-level functional career track progression in typical project control and cost management organization with similar credentials and experience. The functional levels are intermediate, professional, advanced, expert and fellow; which roughly corresponds to career progression from being a fresh graduate getting the first job to becoming a senior practitioner. The author stressed further that the approach enables the integration between the needs of employers who are hiring practitioners who hold these credentials and those individuals and organizations who develop and deliver training to prepare practitioners to qualify for these jobs via the certification process.

Love et al. (2001) emphasized the importance of companies recruiting graduates not to view graduates' acquired education as teaching them about their workplace but as a foundation from which industrial experience will be built into them. As the move towards "outcome" or "results based" education and training, where courses are being designed to prepare people for actual jobs when they graduate, continues to grow; it becomes imperative for those developing/delivering training programs focus on those skills and competencies which are in demand (Giamalvo, 2017). Raiden and Dainty (2006) argued that employers have to leverage on their employees' need for development and also their 
needs in meeting the competitive business environment. In this regard, Chiu and $\mathrm{Ng}$ (2015) recommended that quantity surveying firm managers should place more efforts on improving their employee's job satisfaction to enhance their commitment to the organization. This, according to Chan and Moehler (2008), mandates employers to contribute to the career development of their employees and Chan (2007) sees it as very key to ensuring a sustainable skill base. The outcome of Onukwube (2012)'s study, which established a significant relationship between job satisfaction of quantity surveyors and the work itself, buttressed this view. The study recommended that quantity surveying firms' management should provide opportunities for career growth to quantity surveyors in their employment.

\subsection{The Quantity Surveyor's Career Path system in Nigeria working environment}

Quantity surveyors provide financial and commercial management services on construction projects. They are employed in different working fields within the construction sector. Cartlidge (2009) categorised this, principally, as private practice and contracting organization. Quantity surveyors working in private practice are often described as professional quantity surveyor (PQS) while those in contracting organizations are called contracting quantity surveyors (CQS). They may also work within development companies, commercial organizations, financial institutions and in public sector. As such their involvement in construction projects varies. This is mostly dependent on individual project scheme and mode of procurement (Cunningham, 2014). Traditionally, competence in surveying has been defined by its knowledge base, but the RICS has developed its membership requirements from examination through to a more comprehensive assessment of an acceptable level of proficiency expected of a qualified surveyor, which attempts to be both more carefully defined and also flexible enough to encourage development with changing markets (Westcott and Burnside, 2003).

Due to the vastness of the roles of modern quantity surveyors, a Nigerian graduate quantity surveyor works in different fields and organization with a variety of nomenclature. Nigerian Institute of Quantity Surveyors (NIQS, 2015) categorized these nomenclatures as Public Sector (Federal, States and Local Governments, Ministries, Departments, Agencies and Institutions); Private Sector (Consultancy Practices, Financial Institutions; Oil and Gas Companies; Building and Engineering Firms; Property Development Companies; and so forth). Ikedionwu (2016) summarized the potential employer of quantity surveyors, in Nigeria, into the following categories - consultancy firms; contractors and subcontractors; government and private client organizations. This is illustrated in Figure 1.

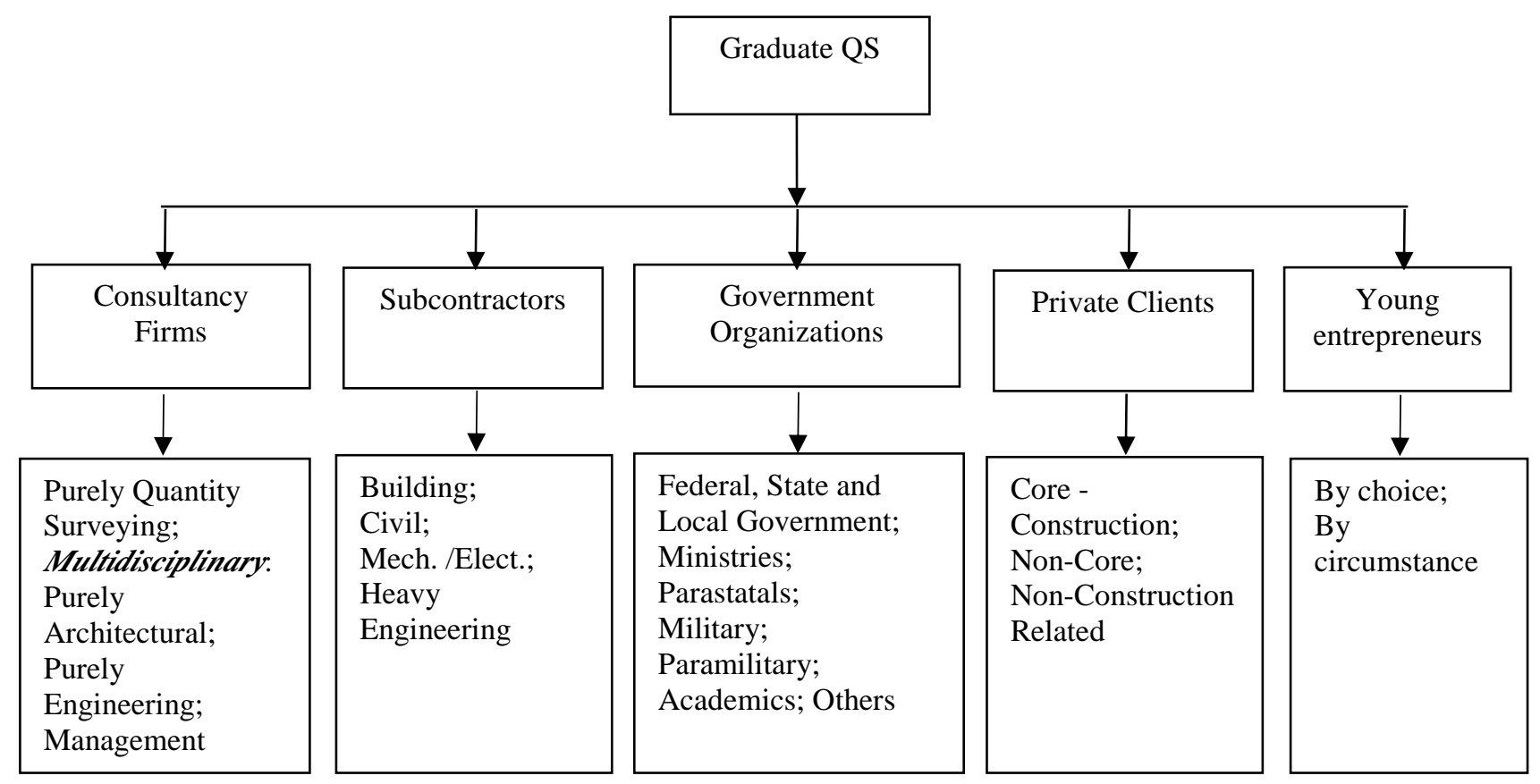

Figure 1: Potential Employers of Quantity Surveyors in Nigeria (Ikedionwu, 2016)

Wherever quantity surveyors work or employed, their roles remain very important in financial accountability, value for money and profitability (Willis et al., 1994) in competitive business environment. The Nigerian Civil (public) Service consists of employees in government agencies other than the military. They progress based on qualifications and seniority. Quantity Surveyors in the Nigeria public service deal with the control of projects in a wide range of sizes as well as maintenance and repair works. Willis et al. (1994) had long given the primary responsibility of quantity surveyors as controlling public money and monitoring the way it is being spent. As earlier reiterated, the key public service for quantity surveyors includes employment in government ministries, departments and agencies. Table 1 gives the scheme of service for quantity surveyors cadre in Nigerian civil service. 
Table 1: Nigerian scheme of service for civil (public) servants (Quantity Surveyor Cadre) (Federal Republic of Nigeria, 2003)

\begin{tabular}{|c|c|c|c|c|c|}
\hline $\mathbf{S} / \mathbf{N}$ & Rank & Entry Qualification & Duties & Salary Scale & Next Rank \\
\hline 1 & $\begin{array}{c}\text { Quantity } \\
\text { Surveyor II }\end{array}$ & $\begin{array}{l}\text { Direct appointment of a candidate } \\
\text { possessing 5 O' level credits } \\
\text { (WASC/NECO/GCE) including } \\
\text { English Language and } \\
\text { Mathematics plus a First Degree in } \\
\text { Quantity Surveying with a } \\
\text { minimum of Second Class Lower } \\
\text { Division. }\end{array}$ & $\begin{array}{l}\text { Assisting in the preparation of } \\
\text { bills of quantities and estimates } \\
\text { of proposed works. } \\
\text { Carrying out valuation for } \\
\text { interim certificates of } \\
\text { payments. } \\
\text { Carrying out other duties as } \\
\text { may be assigned and providing } \\
\text { professional and community } \\
\text { service. }\end{array}$ & $\begin{array}{c}* \text { CONTISS } \\
07\end{array}$ & \\
\hline 2 & $\begin{array}{l}\text { Quantity } \\
\text { Surveyor I }\end{array}$ & $\begin{array}{l}\text { Promotion of a confirmed and } \\
\text { suitable Quantity Surveyor II who } \\
\text { has spent at least three years on the } \\
\text { grade. } \\
\text { Direct appointment of a candidate } \\
\text { possessing (a) First Degree plus } \\
\text { three years post qualification } \\
\text { relevant experience or (b) master's } \\
\text { Degree in relevant area. }\end{array}$ & $\begin{array}{l}\text { Same duties as specified } \\
\text { above. }\end{array}$ & $\begin{array}{l}\text { CONTISS } \\
08\end{array}$ & $\begin{array}{c}\text { Senior } \\
\text { Quantity } \\
\text { Surveyor }\end{array}$ \\
\hline 3 & $\begin{array}{c}\text { Senior } \\
\text { Quantity } \\
\text { Surveyor }\end{array}$ & $\begin{array}{l}\text { Promotion of a confirmed and } \\
\text { suitable Quantity Surveyor I who } \\
\text { has spent at least three years on the } \\
\text { post with satisfactory record of } \\
\text { service } \\
\text { Direct appointment of a candidate } \\
\text { possessing } 5 \text { O' level credits } \\
\text { (WASC/NECO/GCE/) including } \\
\text { English Language and } \\
\text { Mathematics plus (a) First Degree } \\
\text { plus six years post qualification } \\
\text { cognate experience, or (b) } \\
\text { master's Degree plus three years } \\
\text { post-graduation cognate } \\
\text { experience. }\end{array}$ & $\begin{array}{l}\text { Preparing bills, quantities and } \\
\text { estimates of proposed works. } \\
\text { Carrying out valuation for } \\
\text { interim certificates of } \\
\text { payments and serve as } \\
\text { Quantity Surveyor and Cost } \\
\text { Planner on major projects and } \\
\text { control costs of construction } \\
\text { works. } \\
\text { Carrying out other duties as m } \\
\text { ay be assigned } \\
\text { and provide professional' and } \\
\text { community service. } \\
\text { Participating in the preparation } \\
\text { of bills of quantities and } \\
\text { estimates of proposed works. } \\
\text { Carrying out valuation for } \\
\text { interim certificates } \\
\text { payments and serve as } \\
\text { Quantity Surveyor on medium } \\
\text { projects. } \\
\text { Carrying out other duties as } \\
\text { may be assigned and provide } \\
\text { professional and community } \\
\text { service. }\end{array}$ & $\begin{array}{l}\text { CONTISS } \\
09\end{array}$ & $\begin{array}{c}\text { Principal } \\
\text { Quantity } \\
\text { Surveyors }\end{array}$ \\
\hline 4 & $\begin{array}{l}\text { Principal } \\
\text { Quantity } \\
\text { Surveyor }\end{array}$ & $\begin{array}{l}\text { Promotion of a confirmed and } \\
\text { suitable Senior Quantity Surveyor } \\
\text { who has spent at least three years } \\
\text { on the grade. } \\
\text { Direct appointment of a candidate } \\
\text { possessing 5 O' level credits } \\
\text { (WASC/NECO/GCE/) including } \\
\text { English Language and } \\
\text { Mathematics plus (a) First Degree } \\
\text { plus nine years post qualification } \\
\text { experience, or (b) master's Degree } \\
\text { plus six years post qualification } \\
\text { cognate experience }\end{array}$ & $\begin{array}{l}\text { Same as specified in } 3 \text { above. } \\
\text { Assessing financial } \\
\text { implications of project } \\
\text { proposals and advise on cost } \\
\text { decisions. } \\
\text { Carrying out other duties as } \\
\text { may be assigned. }\end{array}$ & $\begin{array}{l}\text { CONTISS } \\
11\end{array}$ & $\begin{array}{c}\text { Chief } \\
\text { Quantity } \\
\text { Surveyor }\end{array}$ \\
\hline
\end{tabular}


Promotion of a confirmed and Preparing bill of quantities and suitable Principal Quantity estimates of proposed works Surveyor who has spent at least and carry out valuation for three years on the grade. interim certificates of payment.

\section{Chief}

5 Quantity Surveyor Serving as Quantity Surveyor and Cost Planner, or Major Projects and control cost of construction works.

$\begin{array}{lrcc}\text { Assessing } & \text { financial } & \text { CONTISS } & \text { Deputy } \\ \text { implications of } & \text { project } & 13 & \text { Director } \\ \text { proposals and advising on cost } & & \end{array}$
decisions and assist in annual capital estimates preparations, review of rolling plans and updating fixed assets register. Carrying out other duties as may be assigned and providing professional and community service.

\begin{tabular}{|c|c|c|c|c|c|}
\hline 6 & $\begin{array}{l}\text { Deputy } \\
\text { director }\end{array}$ & $\begin{array}{l}\text { Promotion of a confirmed and } \\
\text { suitable Chief Quantity Surveyor } \\
\text { who has spent at least three years } \\
\text { on the post. }\end{array}$ & $\begin{array}{l}\text { Performing at higher level, } \\
\text { similar duties specified above. } \\
\text { Carries out other duties as may } \\
\text { be assigned and providing } \\
\text { professional and community } \\
\text { service. }\end{array}$ & $\begin{array}{c}\text { CONTISS } \\
14\end{array}$ & Director \\
\hline 7 & Director & Appointment only. & & $\begin{array}{c}\text { CONTISS } \\
15\end{array}$ & \\
\hline
\end{tabular}

\section{Research Method}

The research methodology adopted for this study includes Delphi survey method. The method involves conduct of rounds of survey on group of experts in a particular field with the intention of eliciting a consensus opinion on an issue (Yousuf, 2007).

In selecting the experts used for this study, a panel drawn from members of the Nigerian Institute of Quantity Surveyors (NIQS) was constituted. Specifically, the chairmen of state chapters and the head of academic institution offering quantity surveying were targeted in the sampling frame. Fifty percent of the functioning 27 state chapter chairs were randomly selected. Of the twenty-nine public institutions offering quantity surveying in Nigeria; seventy-five percent of the heads of department were also randomly selected. Two members of the National Executive Council of the NIQS - chairman of the education committee and that of professional development committee were purposively included. This is as a result of their peculiar portfolio about the training of quantity surveyors. In all, a total number of thirty-eight members panel of experts were included in the survey. The shortlisted members of the panel were written to inform them of their inclusion and the purpose of the study. This gives them the opportunity to accept or dissent their participation. The letter also intimates them of the procedure and guidelines that would be followed.

Structure questionnaire, highlighting various issues of investigation, was designed for the first round of the survey. This gives the participants the opportunity to affirm or comment on the revised and added comments from the anonymous members of the panel. The survey was conducted via registered courier post with adequate follow-up. Twenty-nine members of the panel responded to the first round. Responses for the first round were analysed, and the feedback was used as basis for the second round. Twenty -seven out of the twenty-nine that responded to the first round gave valid response to the second round. Theoretically, Delphi process can be continuously iterated until consensus is determined to have been achieved (Hsu and Sandford, 2007). Custer et al. (1999) also pointed out that three iterations are often sufficient to collect the needed information and to reach a consensus in most situations. However, in this research, two rounds of iteration were conducted to obtain valid results.

In validating the proposed framework, an interview was conducted on small group of quantity surveyors purposively selected based on their long years of experience in the industry. The selection included five quantity surveyors in private practice and two quantity surveyors in academic. An effort was made to ensure that they were not captured in the earlier survey. Specifically, they were interviewed to comment on the appropriateness of the results produced by the consensus opinion and to give their candid view on the process. The interviewees attested to the credibility of the process and the usefulness as well as the relevancy of the proposed framework.

\section{Results, Findings and Discussions}

This section presents and discusses the conceptual career path framework developed from the results of the study. The framework design for a typical quantity surveying firm was adapted from what obtains in the public sector (Table 1). The section involves the process of recruitment (including conduct of interview and aptitude tests); 
post/cadre to be adopted for private practice; as well as qualification and experience required for the respective posts/cadres.

\subsection{Recruitment of Quantity Surveyors}

This section discusses the findings on issues relating to the recruitment of quantity surveyors into the profession. The findings were from the outcome of the final results of the Delphi survey (Tables 2 and 3).

Table 2: Summary of Responses to issues relating to Recruitment of Quantity Surveyors

\begin{tabular}{lcc}
\hline \multicolumn{1}{c}{ Test } & Yes/ (\%) & No/ $(\%)$ \\
\hline $\begin{array}{l}\text { General Knowledge } \\
\text { Professional Knowledge } \\
\text { (specific competencies) }\end{array}$ & $27(100)$ & $0(0)$ \\
$\begin{array}{l}\text { Personal Interview (work } \\
\text { experience) }\end{array}$ & $27(100)$ & $0(0)$ \\
\hline
\end{tabular}

Table 3: Summary of responses to the revised/added comments/suggestions on issues relating to Recruitment of Quantity Surveyors

\begin{tabular}{lcc}
\hline Comment/suggestion & Agree (\%) & Disagree (\%) \\
\hline Spoken/Written English & $26(96.23)$ & $1(3.77)$ \\
ICT & $26(96.23)$ & $1(3.77)$ \\
Industry sector-specific & $19(70.37)$ & $8(29.63)$ \\
knowledge & & \\
Current Affairs & $12(44.44)$ & $15(55.56)$ \\
Human Relation & $25(92.59)$ & $2(7.41)$ \\
\hline
\end{tabular}

The results indicate that new entrants into any cadre of the profession should involve the conduct of series of writing/aptitude tests and should be made to cover: general knowledge, professional knowledge (which addresses specific competencies) and Personal Interview (which addresses work experience). Interview serve as guide and selection process which enables the evaluation of the core competencies expected of quantity surveyor; professional test questions should, therefore, be structured toward them as much as possible. Other areas found to be highly essential and to be addressed are: Spoken/Written English Language, Information and Communication Technology experience, Industrial Specific knowledge and the issue of Human Relations. The issue of spoken /Written English Language is essential as the official language of communication is the English Language. Other identified areas are the specific knowledge which has to do with the basic technical skill and competency requirements which have been documented by various studies. Also; as quantity surveyors will be relating to different stakeholders in the industry and other groups of people and organizations; the issue of human relation is considered very vital in professional practice.

\subsection{Quantity surveyor Career pathway framework for private practice}

From the outcome of the final results of the Delphi survey, the criteria for developing the proposed quantity surveyor career pathway framework is summarized and presented in Tables 4 and 5

Table 4: Summary of Responses to the Proposed Quantity Surveyor Career Pathway Framework

\begin{tabular}{|c|c|c|c|}
\hline Qualification & Post/Cadre & Yes/ $(\%)$ & $\mathrm{No} /(\%)$ \\
\hline ND & Junior Quantity Surveyor & $13(48.15)$ & $14(51.85)$ \\
\hline HND & Assistant Quantity Surveyor & $24(88.89)$ & $3(11.11)$ \\
\hline B.Sc. & Assistant Quantity Surveyor & $24(88.89)$ & $3(11.11)$ \\
\hline HND/B.Sc. plus NIQS professional qualification & Quantity Surveyor & $26(96.31)$ & $1(3.77)$ \\
\hline $\begin{array}{l}\text { M.Sc. plus five years cognate experience but without NIQS } \\
\text { professional qualification }\end{array}$ & Quantity Surveyor & $9(33.33)$ & $18(66.67)$ \\
\hline $\begin{array}{l}\text { HND/B.Sc. plus five years cognate experience and with } \\
\text { NIQS professional qualification }\end{array}$ & Senior Quantity Surveyor & $25(92.59)$ & $2(7.41)$ \\
\hline M.Sc./Ph.D. plus NIQS professional qualification & Senior Quantity Surveyor & $26(96.23)$ & $1(3.77)$ \\
\hline $\begin{array}{l}\text { HND/B.Sc./M.Sc. /Ph.D. plus NIQS professional } \\
\text { qualification and over } 15 \text { years cognate experience }\end{array}$ & Chief Quantity Surveyor & $26(96.23)$ & $1(3.77)$ \\
\hline
\end{tabular}

Table 5: Summary of Responses to the revised/added comments/suggestions to the Proposed Quantity Surveyor Career Pathway Framework

\begin{tabular}{lcc}
\hline \multicolumn{1}{c}{ Comment/suggestion } & Agree (\%) & Disagree (\%) \\
\hline (ND) Trainee QS & $17(62.96)$ & $10(37.04)$ \\
\hline (ND) QS Assistant & $6(22.22)$ & $21(77.78)$ \\
\hline (ND) Estimator & $2(7.41)$ & $25(92.59)$ \\
\hline (ND) QS Technician & $2(7.41)$ & $25(92.59)$ \\
\hline (HND) Higher Technical & $7(25.93)$ & $20(74.07)$ \\
Officer & & \\
\hline (HND) QS Trainee & $2(7.41)$ & $25(92.59)$ \\
\hline (B.Sc.) Pupil QS & $7(25.93)$ & $20(74.07)$ \\
\hline (B.Sc.) QS II & $11(40.74)$ & $16(59.26)$ \\
\hline
\end{tabular}

\begin{tabular}{lcc}
\hline (HND/B.Sc. +MNIQS) QS I & $10(37.04)$ & $17(62.96)$ \\
\hline (HND/B.Sc. +MNIQS) & $4(14.81)$ & $23(85.19)$ \\
Senior QS & & \\
\hline (HND/B.Sc. +MNIQS+2yrs & $22(81.48)$ & $5(18.52)$ \\
*exp.) Senior QS & $23(85.19)$ & $4(14.81)$ \\
\hline (HND/B.Sc. & \\
+MNIQS+10yrs exp.) \\
Principal QS
\end{tabular}




\begin{tabular}{|c|c|c|}
\hline $\begin{array}{l}\text { (HND/B.Sc.+MNIQS+25yrs } \\
\text { exp.) Principal Consultant }\end{array}$ & $19(70.37)$ & $8(29.63)$ \\
\hline $\begin{array}{l}\text { Candidate to pass NIQS and } \\
\text { reg. with QSRBN before } \\
\text { called QS }\end{array}$ & $20(74.07)$ & $7(25.93)$ \\
\hline
\end{tabular}

Table 6 presents the developed conceptual framework which detailed the agreed posts/cadres to be adopted in private practice as well as the qualifications and experience to match them. This ranges from the trainee quantity surveyor, assistant quantity surveyor, through principal partner/consultant. A holder of the lowest degree (ND) is to be regarded as trainee, while holder of HND/B.Sc. is to be regarded as assistant quantity surveyors. Any candidate with HND/B.Sc. moreover, who has passed the professional examination and registered with the QSRBN should be regarded as quantity surveyor. From this premise, it is to be noted that before anybody is called quantity surveyor, he/she must have passed the professional examinations and duly registered with the QSRBN. Subsequent cadres have to do with post qualification and years of experience. Adopting this policy in private practice is seen as good development which will engender uniformity among quantity surveying practitioners.

Table 6: Framework for Quantity Surveyors' Career Path in Private Practice

\begin{tabular}{ll}
\hline \multicolumn{1}{c}{ Post/Cadre } & \multicolumn{1}{c}{$\begin{array}{c}\text { Qualifications and } \\
\text { experiences }\end{array}$} \\
$\begin{array}{l}\text { Trainee Quantity } \\
\text { Surveyor }\end{array}$ & ND \\
\hline $\begin{array}{l}\text { Assistant Quantity } \\
\text { Surveyor }\end{array}$ & HND/B.Sc. \\
\hline Quantity Surveyor & $\begin{array}{l}\text { HND/B.Sc. + NIQS } \\
\text { professional qualification }\end{array}$ \\
\hline Senior Quantity Surveyor & $\begin{array}{l}\text { HND/B.Sc. }+ \text { NIQS } \\
\text { professional qualification }+5 \\
\text { years cognate experience }\end{array}$ \\
\hline $\begin{array}{l}\text { Principal Quantity } \\
\text { Surveyor }\end{array}$ & $\begin{array}{l}\text { HND/B.Sc. }+ \text { NIQS } \\
\text { professional qualification }+ \\
10 \text { years cognate experience }\end{array}$ \\
\hline Chief Quantity Surveyor & $\begin{array}{l}\text { HND/B.Sc. + NIQS } \\
\text { professional qualification }+ \\
15 \text { years cognate experience }\end{array}$ \\
\hline Partner & $\begin{array}{l}\text { HND/B.Sc. }+ \text { NIQS } \\
\text { professional qualification }+ \\
15 \text { years cognate experience }\end{array}$ \\
\hline Principal & $\begin{array}{l}\text { HND/B.Sc. + NIQS } \\
\text { professional qualification }+ \\
\text { Partner/Consultant }\end{array}$ \\
\hline Post/Cadre & $\begin{array}{l}\text { Qualifications and } \\
\text { experiences }\end{array}$ \\
\hline
\end{tabular}

Trainee quantity surveyor cadre

For the post of trainee quantity surveyor, the prospective applicant must have at least OND in quantity surveying from an accredited institution. Creation of this cadre in the professional development cycle helps the career development of quantity surveying graduates up to managerial levels.

\section{Assistance quantity surveyor cadre}

For the post of assistance quantity surveyor, the prospective applicant must have at least first degree (HND or B.Sc. quantity surveying) from an accredited institution. Fresh graduates will mostly fall into this category. This is because of the limited professional training or experience (as indicated in the framework). This cadre affords an individual while working in a quantity surveying firm, to commence the professional certification process. It also affords the firm to create a platform for sponsoring their employee in this regard.

\section{Quantity surveyor cadre}

To be qualified for this post of quantity surveyor, the prospective applicant must have at least HND or B.Sc. in quantity surveying from an accredited institution and must have passed the Test of Professional Competence (TPC)/Graduateship Examination and the Professional Competence Interview (PCI) conducted by the institute. Also, candidates must have a minimum of two years experience after graduation (inclusive of the "National Youth Service Corps - NYSC year), completed and passed assessment of logbook and diary of experience for two years and registered with the QSRBN. Any candidate with these qualifications are automatically regarded and recognized as qualified quantity surveyor.

\section{Senior quantity surveyor, Principal quantity surveyor, Chief quantity surveyor, and Principal Partner/Consultant cadres}

These cadres have to do with post qualification couple with the number of years of experience. The experience garnered over time goes a long way to affecting the proficiency level of an employee. The experience often comes in the form of continuing professional development. A proactive framework, to ensuring that the experience garner over time is adequately rewarded by way of moving up the ladder with corresponding benefits, is therefore considered highly imperative. This will not only encourage an employee to put in more effort, but it will also help in the stability of the organization.

\section{Conclusions and Recommendations}

In response to bridging the gap and resolving the dichotomy that exists in quantity surveyors' recruitment, placement and promotion in private practice in comparison with that of public service in Nigeria working environment; this study was aimed at providing a framework that could serve as a regulated scheme of service and career pathway metrics for quantity surveyor employees in private practice. From the consensus obtained from a panel of expert, a conceptual framework for career path and development of quantity surveyors employees in private practice is proposed. The framework which detailed the agreed posts/cadres to be adopted in private practice as well as the qualifications and experience to match them, ranges from the trainee quantity surveyor, assistant quantity surveyor, through principal partner/consultant. The implications of the study 
have a direct effect on the employers of quantity surveyors in private practice, the potential (quantity surveyor) employees and quantity surveying service delivery in general. For employers, who are looking for people to hire, the framework can help in drafting better job descriptions internally as well as help the human resource team shortlist candidates and conduct the initial interviews. This has profound implications when trying to evaluate potential employees for respective positions and more importantly when evaluating job changes or responsibility assignments within the organization. This also has relevance for potential employees who are preparing for careers in quantity surveying to help them develop more effective career path development plans. Defined career path framework can improve performances. Employees become familiar with their career progression, and eventually, the entire organization begins to speak consistently when talking about its

\section{References}

Anunike, E. B. (2016) Progression in Post-Graduate professional qualifications and

development of the Quantity Surveyors in Nigeria. A paper presented at the 2016 Annual Academic Seminar of the National Association of Quantity Surveying Students (Obafemi Awolowo University Chapter), Obafemi Awolowo University, Ile-Ife, Nigeria.

Ariffin, M.H. and Torrance, A.J. (2008). Social group related entry participation motivations for continuing professional development activities among Malaysian Registered Quantity Surveyors. Journal of Construction in Developing Countries, 13 (2), 1-19.

Australian Institute of Quantity Surveyors (AIQS). (2004) World's Best Practice in Quantity Surveying. What it means to you. AIQS Brochure.

Board of Quantity Surveyors, Malaysia (BQSM) (2004). Guidelines on Continuing Professional Development for Quantity Surveyors. Kuala, Lumpur.

Cartlidge, D. (2009) Quantity Surveyor's Pocket Book, Butterworth Heinemann, Oxford.

Center for Postsecondary and Economic Success (2013) The Alliance for Quality

Career Pathways Approach: Developing Criteria and Metrics for Quality Career Pathways. Available from http//www.clasp.org. [Accessed on February 06 2016]

Chan, P. (2007) Managing human resources without human resources management

departments: some exploratory findings on a construction project. In Huges, W. (Ed.) Proceedings of the CME25 Conference "Construction management and economics: past, present and future", University of Readings, UK, 16-18.

Chan, P. and Moehler, R. (2008) Developing a 'roadmap' to facilitate employers' role in

engaging with the skills development agenda. Northumbria Working Paper Series: Interdisciplinary Studies in the Built and Virtual Environment, 1(1), 15-24.

Chiu, W.Y.B and Ng, F.F. (2015) The Mediation Influence of Job Satisfaction on Organisational Commitment amongst Quantity Surveyors, Construction Economics and Building, 15(1), 56-74. DOI: http://dx.doi.org/10.5130/ajceb.v15i1.4304 employees' professional development goals. This is seen to take account of and encourage the career management of prospective employee which is vital to high-quality service delivery. By this means, organizational effectiveness coupled with employee satisfaction can be enhanced and thereby give a win-win situation.

While this study focused majorly on placement and promotion for quantity surveyors; future study is recommended on establishing a uniform, equitable remuneration for the respective cadres in the proposed framework and job description for each cadre. This will further concretize the framework and make it more applicable to a scheme of service in the private practice as obtainable in the public service. Furthermore, the study can be extended, in context, to other construction professionals in Nigeria.

Collins English Dictionary (2012) Collins English Dictionary - Complete \& Unabridged 10th Edition, Williams Collins Sons and Co. Ltd. Available from http://www.dictionary.com/browse/career [Accessed January 6, 2017]

Cunningham, T. (2014) The Work and Skills Base of the Quantity Surveyor in Ireland -

An Introduction. ARROW @DIT, School of Surveying and Construction Management, Dublin Institute of Technology, Dublin.

Custer, R.L., Scarcella, J.A. and Stewart, B.R. (1999). The modified Delphi technique: A rational modification. Journal of Vocational and Technical Education, 15(2), 1 - 10.

Federal Republic of Nigeria (2003) Scheme of service for use in the civil service of the Federation. Office of the Head, Civil Service of the Federation

Giammalvo, P.D. (2016) Cost Estimator/Quantity Surveyor Defined - A Key Word Analysis of Current Job Descriptions as the Basis for Exam and Competency Assessment Scoring Models. Featured Paper. PM World Journal 5(7), 1-14. Available from http://www.pmworldjournal.net. [Accessed January 16, 2017].

Giammalvo, P.D. (2017) Business Analyst, Cost Engineer, Project Manager and Systems Engineer Compared - A Key Word Analysis of Current Job Descriptions To Analyze Project Management Related Job Roles and Responsibilities. Featured Paper. PM World Journal 7(1), 1-19. Available from http://www.pmworldjournal.net. [Accessed January 16, 2017].

Githaiga, F.M. (2004) Challenges facing the Quantity Surveying Profession in a Globalized Economy. Proceedings of the 21st Biennial Conference of Nigerian Institute of Quantity Surveyors (NIQS) on " Adding Value to a Reforming Challenges for the Quantity Surveying Profession in Nigeria. $24-27$ th November, Premier Hotel, Ibadan, Nigeria.

Grugulis, I. (2003) The contribution of National Vocational Qualification to the growth of

skills in the UK, British Journal of industrial relations, 41(3), 457-475. 
Heatfield, S.M. (2014) Career Pathing. [Online]. Available from http://humanresources.about.com/od/glossaryc/g/careerpathing.htm. [Accessed 18 December 2015]

Hollmann, J.K. and Elliot, B.G. (2006). Core Competencies, Expectations and Career Path for an Estimating Professional. AACE International Transaction, AACE International, Morgantown, MV.

Hooley, T. (2012) "How the internet changed career: framing the relationship between career development and online technologies". Journal of the National Institute for Career Education and Counseling (NICEC) 29: 3.

Hooley, T., Watts, A. G., Sultana, R. G., and Neary, S. (2013). "The 'blueprint' framework for career management skills: a critical exploration". British Journal of Guidance \& Counseling 41(2), 117, doi:10.1080/03069885.2012.713908

Hrzone (2016) What is a Career Path [Online]. Available from

http://www.reference.business.com/management/

[Accessed: 15 November 2016]

Hsu, C. and Sandford, B.A. (2007). The Delphi Technique: Making Sense of Consensus. Practical Assessment, Research and Evaluation, 12(10). Available from http://pareonline.net/getyn.asp? $\mathrm{y}=12 \& \mathrm{n}=10$. [Accessed 21 May 2016].

Ikedionwu, C.C. (2016) Quantity surveying professional career path: A multi-

dimensional perspective. A paper presented at 2016 Annual Academic Seminar of the National Association of Quantity Surveying Students (NAQSS), Obafemi Awolowo University, Ile-Ife, Nigeria.

Love, P.E.D., Haynes, N.S. and Irani, Z. (2001) Construction managers' expectations and observations of graduates. Journal of Managerial Psychology, 16 (8), 579593.

National Career Pathways Network (2012) Career Pathways [Online]. Available from

http://www.cord.org/career-pathways/. [Accessed 26 August 2016]

Nigerian Institute of Quantity Surveyors (2015) Corporate Strategy Action Plan, NIQS, Nigeria.

Nkado, R. and Meyer, T. (2001). Competencies of professional quantity surveyors: South African perspective. Construction Management and Economics. $19,481-491$.

Onukwube, H. N. (2012) 'Correlates of job satisfaction amongst quantity surveyors in consulting firms in Lagos, Nigeria', Australasian Journal of Construction Economics and Building, 12 (2) 43-54
Pacific Association of Quantity Surveyors (2001). Competency Standard for Quantity Surveyors in the Asian-Pacific Region. Available from http://www.paquantity surveyor.net. [Accessed 02 December 2015].

Pheng, L.S. and Ming, K.H. (1997) Formulating a strategic marketing mix for quantity surveyors. Marketing Intelligence and Planning, 15 (6), 273-280.

Raiden, A. and Dainty, A. (2006) Human Resource Development in Construction Organisations. The Learning Organisation, 13(1), 63-79.

Royal Institution of Chartered Surveyors (RICS) (1971) The future role of Quantity Surveyors, RICS, London.

Royal Institution of Chartered Surveyors (1993). CPD - Review of policy and future strategy, Wentwood Way, Coventry, UK.

Royal Institution of Chartered Surveyors (1998). The APC Requirement and Competencies, London.

Society for Human Resources Management (2015) Developing Employee career paths and Ladders. Available from https://www.shrm.org/resourcesandtools/tools-andsamples/toolkits/pages/developingemployeecareerpathsa ndladders.aspx. [Accessed January 16, 2017].

Towey, D. (2012) Construction Quantity Surveying: A Practical Guide for the

Contractor's Quantity Surveyor. Wiley-Blackwell, UK. VFM Group (2008) Quantity Surveyors/Cost Management [Online]. Available from

http://www.vfmgroup.com. [Accessed 13 January 2017].

Westcott, A.J. and Burnside, K. (2003) Educating for competency in construction

economics and management: International Conference of the Institute of surveyors and CASLE on Construction Economics and Management with particular reference to developing countries, 3-5th March, New Delhi.

Willis, C.J., Ashworth, A. And Willis, J.A. (1994), Practice and Procedure for the Quantity Surveyor, 10th ed., Oxford: Blackwell Science.

Worthen, B.R. and Sanders, J.R. (1987). Educational evaluation. Alternatives approaches and practical guidelines. New York: Longman.

Yousuf, M. 1. (2007). Using Experts' Opinions through Delphi Technique. Practical Assessment, Research and Evaluation, 12(4). Available from http://pareonline.net/getyn.asp?v=12\&n=4. [Accessed 21 May 2016]. 